\title{
Effect of Feeding Shatavari (Asparagus racemosus) Root Powder on Certain Blood Mineral Profile of Crossbred Cows
}

\author{
Vijay Prakash Saini $^{{ }^{*}}$ and Sheela Choudhary ${ }^{2}$ \\ ${ }^{1}$ Mahatma Jyotiba Fule College of Veterinary \& Animal Sciences Chomu, \\ Jaipur - 303702, India \\ ${ }^{2}$ Department of Animal Nutrition, Post Graduate Institute of Veterinary Education and \\ Research, Jaipur - 302031, India \\ *Corresponding author
}

A B S T R A C T

\begin{tabular}{|l|}
\hline Ke y w o r d s \\
Shatavari, serum, \\
Mineral \\
\hline Article Info \\
\hline $\begin{array}{l}\text { Accepted: } \\
\text { 10 August } 2018 \\
\text { Available Online: } \\
\text { 10 September } 2018\end{array}$ \\
\hline
\end{tabular}

Present study was conducted to evaluate the effect of herbal feed supplement shatavari (Asparagus racemosus) in terms of certain blood mineral profile of crossbred cows. The cows were divided in four groups. Group $G_{1}$ was control group, in which the animals receive experimental feed without any other feed supplements, whereas the animals of experimental group $2\left(\mathrm{G}_{2}\right)$, group $3\left(\mathrm{G}_{3}\right)$ and group $4\left(\mathrm{G}_{4}\right)$ were fed a similar feed along with shatavari root powder $40 \mathrm{gm}, 80 \mathrm{gm}$ and $120 \mathrm{gm}$ respectively. The study was conducted for a period of 60 days including 7 days digestibility trial. Statistical analysis of average serum calcium data revealed non-significant effect due to supplementation of herb shatavari. Significant $(\mathrm{P} \leq 0.05)$ effect on serum phosphorus and highly significant $(\mathrm{P} \leq 0.01)$ effect on magnesium was observed. Statistical analysis of data revealed highly significant $(\mathrm{P} \leq 0.01)$ effect on zinc and copper also due to supplementation of herb shatavari.

\section{Introduction}

Use of herbal plants is considered to be safe for enhancing the nutrient utilization and productivity of ruminants without having side effects. Realizing this, some of the herbs have been identified viz. Asparagus racemosus (Shatavari), Bacopamonnieri (Brahmi), Eclipta alba (Bhringraj) and Leptadenia reticulata (Jiwanti) which in turn may improve the efficiency of utilization of nutrients. Feed additives that modify rumen fermentation such as organic acids, yeast, enzymes and ionophores are being used to optimize performance in animal production systems. Traditionally some herbs or their mixtures are used to promote feed intake due to their flavouring and medicinal properties for enhancing production of livestock.

Asparagus racemosusis most commonly used in indigenous medicine. Locally this plant is called shatawar in Hindi and in central himalayan region this plant is called satmuli (shata means hundred and muli means roots). In Sanskrit this plant is called shatavari which means 'able to have one hundred husbands' and in Ayurveda this amazing herb is known as the "queen of herbs". Asparagus racemosus may constitute a very important component of 
feed supplement in the animal diet because of the higher availability of nutrients. Crude protein, crude fiber, ether extract, nitrogen free extract and ash content have been analyzed. Choudhary and Kar (1992) recorded that shatavari root is rich source of minerals and it contains macro minerals such as $\mathrm{Ca}$, $\mathrm{Mg}, \mathrm{K}$ and $\mathrm{Fe}$ having concentration of 0.22 , $0.40,2.50$ and $0.01 \mathrm{~g} / 100 \mathrm{~g}$, respectively and micro minerals such as $\mathrm{Cu}, \mathrm{Zn}, \mathrm{Mn}, \mathrm{Co}$ and $\mathrm{Cr}$ having concentration of 5.29, 53.15, 19.98, 22.0 and $1.81 \mu / \mathrm{gm}$, respectively. In fact use of herbs as feed additive is experiencing resurgence in animal health and production. Supplementation of a mixture of herbs as a feed additive improved the utilization of nutrients and had beneficial effect on growth in crossbred heifers (Gupta et al., 2005).

The tuberous roots of Shatavari (Asparagus racemosus) are well known for their galactogogue and anabolic activity (Chopra et al., 1956) and it appears in many ayurvedic preparations as growth promoters and immune-stimulant. Therefore keeping the aforesaid facts in view, the present experiment was designed to elucidate the effect of herbal feed supplement of Shatavari (Asparagus racemosus) on blood mineral profilein crossbred cows.

\section{Materials and Methods}

The study was taken up in Jaipur district of Rajasthan. Sixteen crossbred cows of almost same stage of lactation and milk yield were selected and distributed into four groups of four each from the herd of Shri Pinjarapole Gaushala, Sanganer, Jaipur. All the cows were maintained under stall feeding.

\section{Housing and management of cows}

All crossbred cows were housed in a wellventilated byre having concrete floor with individual feeding arrangement and tied with iron chain at such a distance that they had freedom for free movement but preventing them to access the manger of other cows. All the crossbred cows under the present study had their identification number uniquely tagged on the ear. Cows were stall fed throughout the experimental period. Fresh and clean water was provided thrice a day i.e. morning, afternoon and evening throughout the experimentation. Animals were given prophylactic dose of anthelmintic 15 days prior to start of experiment. Proper hygienic conditions and healthy surrounding were maintained in the shed throughout the experimental feeding period. During the research period, health status of cows was monitored regularly. Crossbred cows were fed as per ICAR (2013) feeding standards to meet the requirement of nutrients for 60 days. Wheat straw was offered daily ad lib in morning. The leftover was removed on the next day morning. Shatavari root powder was supplemented daily by mixing in the concentrate. An adaptation period of 15 days was observed prior to start of experimental feeding trial. Thereafter, cows were distributed into four groups of four animals each in such a way that each group had almost similar stage of lactation and milk yield. Cows were then placed on four dietary experimental feeds (Table 1). Deworming of the cows was done twice by fenbendazole bolus at an interval of two weeks and shatavari root powder feeding was initiated after second deworming.

The experimental group $G_{1}$ that was control group receiving experimental feed consisting of wheat straw and readymade concentrates. Crossbred cows of the experimental group $\mathrm{G}_{2}$ were fed wheat straw and readymade concentrate with shatavari root powder @ 40 $\mathrm{gm} /$ day/cow for 60 days. Crossbred cows of the experimental group $\mathrm{G}_{3}$ were fed wheat straw and readymade concentrate with shatavari root powder @ 80 gm/day/cow for 
60 days. Crossbred cows of the experimental group $\mathrm{G}_{4}$ were fed wheat straw and readymade concentrate with shatavari root powder @ 120 $\mathrm{gm} / \mathrm{day} / \mathrm{cow}$ for 60 days. The shatavari root powder was made available by Nutri Care Animal Feed, Sanganer, Jaipur.

The blood samples of experimental cows were collected monthly i.e. 0,30 and 60 days at 8.00 AM in morning before feeding and watering. Blood was collected from jugular vein with all aseptic precautions using 20 gauge needles to avoid rupture of corpuscles, damage of leucocytes and to allow flow of blood smoothly with a minimum of vacuum. For separation of serum, blood was collected in a blood collection tube, without anticoagulant and kept in slanting position. These tubes were incubated for 1 hour at $37^{\circ} \mathrm{C}$. Blood clots were broken and tubes were centrifuged at $2500 \mathrm{rpm}$ for 30 minutes. The serum was pipette out in small pyrex tubes and kept for further analysis of serum mineral profile

\section{Analysis of blood samples}

In the digestion of serum samples, representative sample of $1 \mathrm{ml}$ serum was transferred into $100 \mathrm{ml} \mathrm{Kjeldhal} \mathrm{flask} \mathrm{and} \mathrm{was}$ digested with triple acid digestion method (Ghosal and Mathur, 1988). Minerals were estimated after diluting by 1:21 with 20 per cent TCA and the supernatant taken for estimation. All minerals were estimated with atomic absorption "spectrophotometer" (model Shimadzu-AA-6300).

\section{Results and Discussion}

\section{Serum mineral profile}

\section{Serum calcium}

The mean serum calcium concentrations $(\mathrm{mg} / \mathrm{dl})$ for the experimental period are presented in Table 2 and illustrated in Figure 1. The statistical analysis of data revealed nonsignificant effect due to supplementation of herb shatavari root powder. The maximum serum calcium was found in $\mathrm{G}_{4}$ group followed by $\mathrm{G}_{3}$ and $\mathrm{G}_{1}$ groups and minimum in $\mathrm{G}_{2}$ group.

\section{Serum phosphorus}

The mean serum phosphorus concentrations $(\mathrm{mg} / \mathrm{dl})$ for the experimental period are presented in Table 3and illustrated in Figure 2. The statistical analysis of data revealed significant $(\mathrm{P} \leq 0.05)$ effect due to supplementation of herb shatavari root powder. The maximum serum phosphorus was found in $G_{3}$ and $G_{4}$ groups followed by $G_{2}$ group and minimum in $\mathrm{G}_{1}$ group. Results indicates that neither $G_{1}$ and $G_{2}$ groups nor $G_{3}$ and $\mathrm{G}_{4}$ groups differ non significantly from each other but $G_{3}$ and $G_{4}$ groups differs significantly from $G_{1}$ and $G_{2}$ groups.

\section{Serum magnesium}

The mean serum magnesium concentrations $(\mathrm{mg} / \mathrm{dl})$ for the experimental period are presented in Table 4 and illustrated in Figure 3. The statistical analysis of data revealed highly significant $(\mathrm{P} \leq 0.01)$ effect due to supplementation of herb shatavari.

The maximum serum magnesium was found in $G_{4}$ group followed by $G_{3}$ and $G_{4}$ groups and minimum in $G_{1}$ group. Non-significant difference was observed between $G_{1}$ and $G_{2}$ groups and also between $\mathrm{G}_{3}$ and $\mathrm{G}_{4}$ groups but $G_{3}$ and $G_{4}$ groups differ significantly from $G_{1}$ and $\mathrm{G}_{2}$ groups.

\section{Serum zinc}

The mean serum zinc (ppm) concentrations for the experimental period are presented in Table 5 and illustrated in Figure 4. 
Table.1 Experimental feeds offers to crossbred cows in different treatment groups

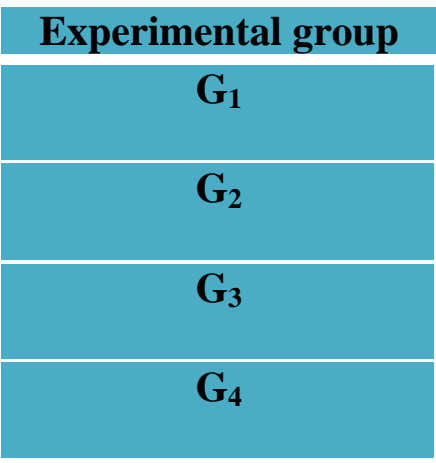

\section{Experimental feed}

Wheat straw + Readymade concentrate (without shatavari root powder)

Wheat straw + Readymade concentrate + Shatavari root powder (40 gm/day/animal)

Wheat straw + Readymade concentrate + Shatavari root powder (80 gm/day/animal)

Wheat straw + Readymade concentrate + Shatavari root powder (120 gm/day/animal)

Table.2 Mean \pm S.E.M. values of serum calcium $(\mathrm{mg} / \mathrm{dl})$ in different treatment groups

\begin{tabular}{|c|c|c|c|c|c|}
\hline \multirow{2}{*}{ Group } & \multicolumn{3}{|c|}{ Period in days } & Overall mean & SEM \\
\hline $\mathbf{G}_{\mathbf{1}}$ & $\mathbf{0}$ & $\mathbf{3 0}$ & $\mathbf{6 0}$ & & \\
\hline $\mathbf{G}_{\mathbf{2}}$ & 12.95 & 12.50 & 13.22 & 12.89 & \\
\hline $\mathbf{G}_{\mathbf{3}}$ & 11.92 & 12.72 & 13.60 & 12.75 & 0.48 \\
\hline $\mathbf{G}_{\mathbf{4}}$ & 10.77 & 13.55 & 15.80 & 13.37 & \\
\hline
\end{tabular}

Means with different superscripts differ significantly within the column

Table.3 Mean \pm S.E.M. values of serum phosphorus $(\mathrm{mg} / \mathrm{dl})$ in different treatment groups

\begin{tabular}{|c|c|c|c|c|c|}
\hline Group & \multicolumn{3}{|c|}{ Period in days } & Overall mean & SEM \\
\hline & $\mathbf{0}$ & $\mathbf{3 0}$ & $\mathbf{6 0}$ & & \\
\hline $\mathbf{G}_{\mathbf{1}}$ & 6.10 & 6.12 & 6.22 & $6.15^{\mathrm{a}}$ & \\
\hline $\mathbf{G}_{\mathbf{2}}$ & 5.97 & 6.75 & 7.03 & $6.58^{\mathrm{a}}$ & 0.21 \\
\hline $\mathbf{G}_{\mathbf{3}}$ & 6.62 & 7.00 & 7.97 & $7.20^{\mathrm{b}}$ & \\
\hline $\mathbf{G}_{\mathbf{4}}$ & 6.30 & 7.22 & 8.07 & $7.20^{\mathrm{b}}$ & \\
\hline
\end{tabular}

Means with different superscripts differ significantly within the column

Table.4 Mean \pm S.E.M. values of serum magnesium $(\mathrm{mg} / \mathrm{dl})$ in different treatment groups

\begin{tabular}{|c|c|c|c|c|c|}
\hline Group & \multicolumn{3}{|c|}{ Period in days } & Overall mean & SEM \\
\hline $\mathbf{G}_{\mathbf{1}}$ & $\mathbf{0}$ & $\mathbf{3 0}$ & $\mathbf{6 0}$ & & \\
\hline $\mathbf{G}_{\mathbf{2}}$ & 1.97 & 1.77 & 2.05 & $1.93 \pm 0.13^{\mathrm{a}}$ & \\
\hline $\mathbf{G}_{\mathbf{3}}$ & 1.67 & 2.45 & 2.65 & $2.25 \pm 0.13^{\mathrm{a}}$ & 0.13 \\
\hline $\mathbf{G}_{\mathbf{4}}$ & 2.35 & 3.07 & 3.47 & $2.96 \pm 0.13^{\mathrm{b}}$ & \\
\hline
\end{tabular}

Means with different superscripts differ significantly within the column 
Table.5 Mean \pm S.E.M. values of serum zinc (ppm) in different treatment groups

\begin{tabular}{|c|c|c|c|c|c|}
\hline & \multicolumn{3}{|c|}{ Period in days } & Overall mean & SEM \\
\hline $\mathbf{G}_{\mathbf{1}}$ & $\mathbf{0}$ & $\mathbf{3 0}$ & $\mathbf{6 0}$ & & \\
\hline $\mathbf{G}_{\mathbf{2}}$ & 0.90 & 0.90 & 0.93 & $0.91^{\mathrm{a}}$ & \\
\hline $\mathbf{G}_{\mathbf{3}}$ & 0.89 & 0.99 & 1.03 & $0.97^{\mathrm{a}}$ & 0.03 \\
\hline $\mathbf{G}_{\mathbf{4}}$ & 0.93 & 1.16 & 1.24 & $1.11^{\mathrm{b}}$ & \\
\hline & 0.92 & 1.17 & 1.20 & $1.10^{\mathrm{b}}$ & \\
\hline
\end{tabular}

Means with different superscripts differ significantly within the column

Table.6 Mean \pm S.E.M. values of serum copper $(\mathrm{ppm})$ in different treatment groups

\begin{tabular}{|c|c|c|c|c|c|}
\hline Group & \multicolumn{3}{|c|}{ Period in days } & Overall mean & SEM \\
\hline $\mathbf{G}_{\mathbf{1}}$ & $\mathbf{0}$ & $\mathbf{3 0}$ & $\mathbf{6 0}$ & & \\
\hline $\mathbf{G}_{\mathbf{2}}$ & 0.67 & 0.73 & 0.75 & $0.72^{\mathrm{a}}$ & \\
\hline $\mathbf{G}_{\mathbf{3}}$ & 0.63 & 1.15 & 1.21 & $1.00^{\mathrm{b}}$ & 0.03 \\
\hline $\mathbf{G}_{\mathbf{4}}$ & 0.69 & 1.08 & 1.14 & $0.97^{\mathrm{b}}$ & \\
\hline
\end{tabular}

Means with different superscripts differ significantly within the column

Fig. 1. Effect of herbal feed supplement shatavari on serum calcium

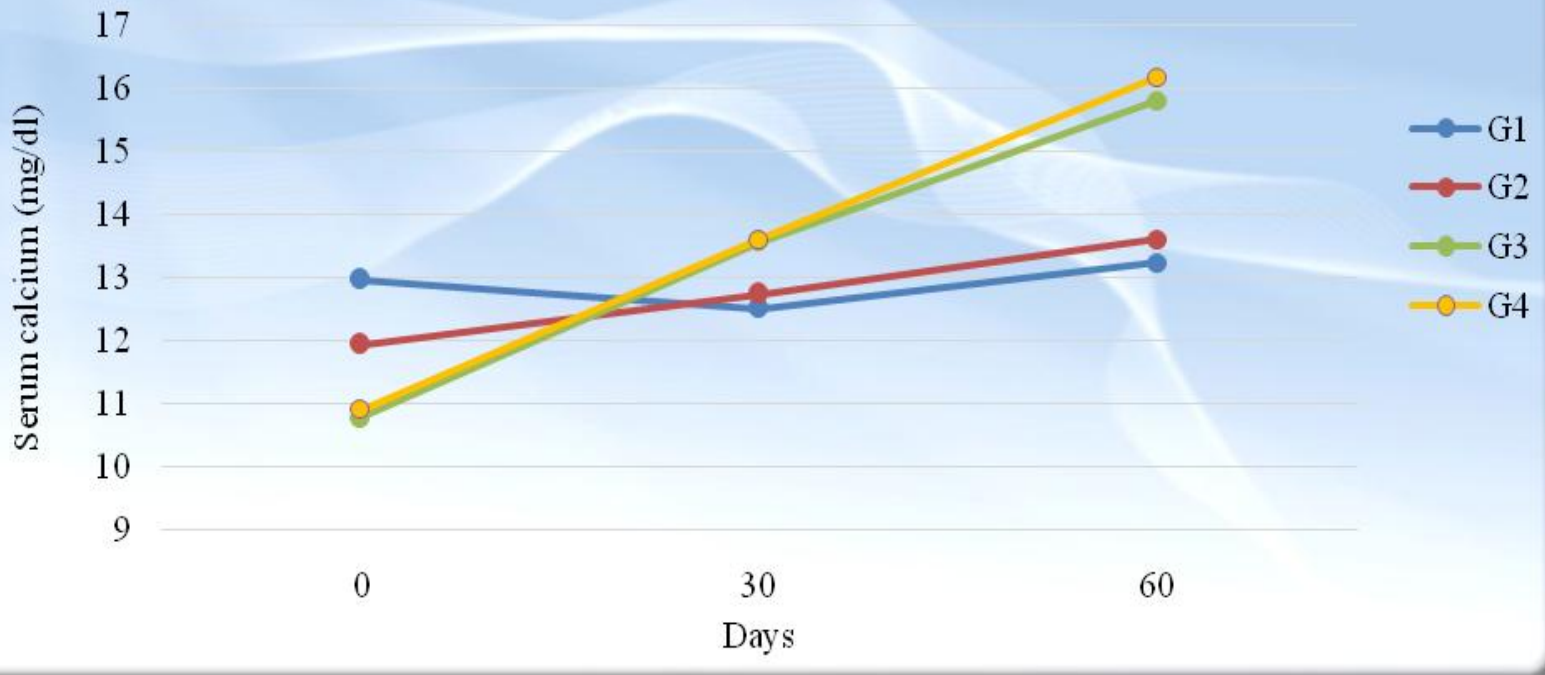



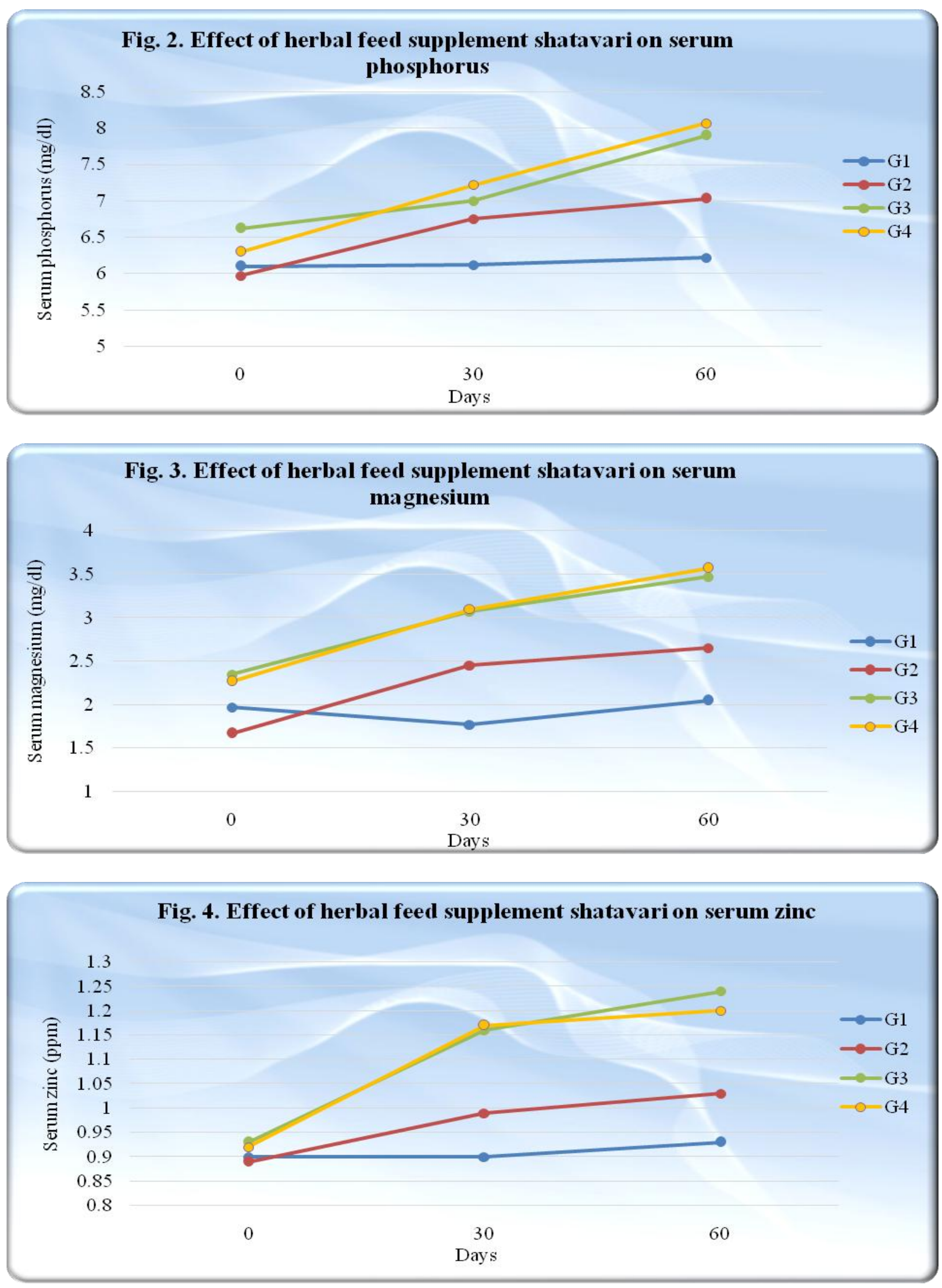


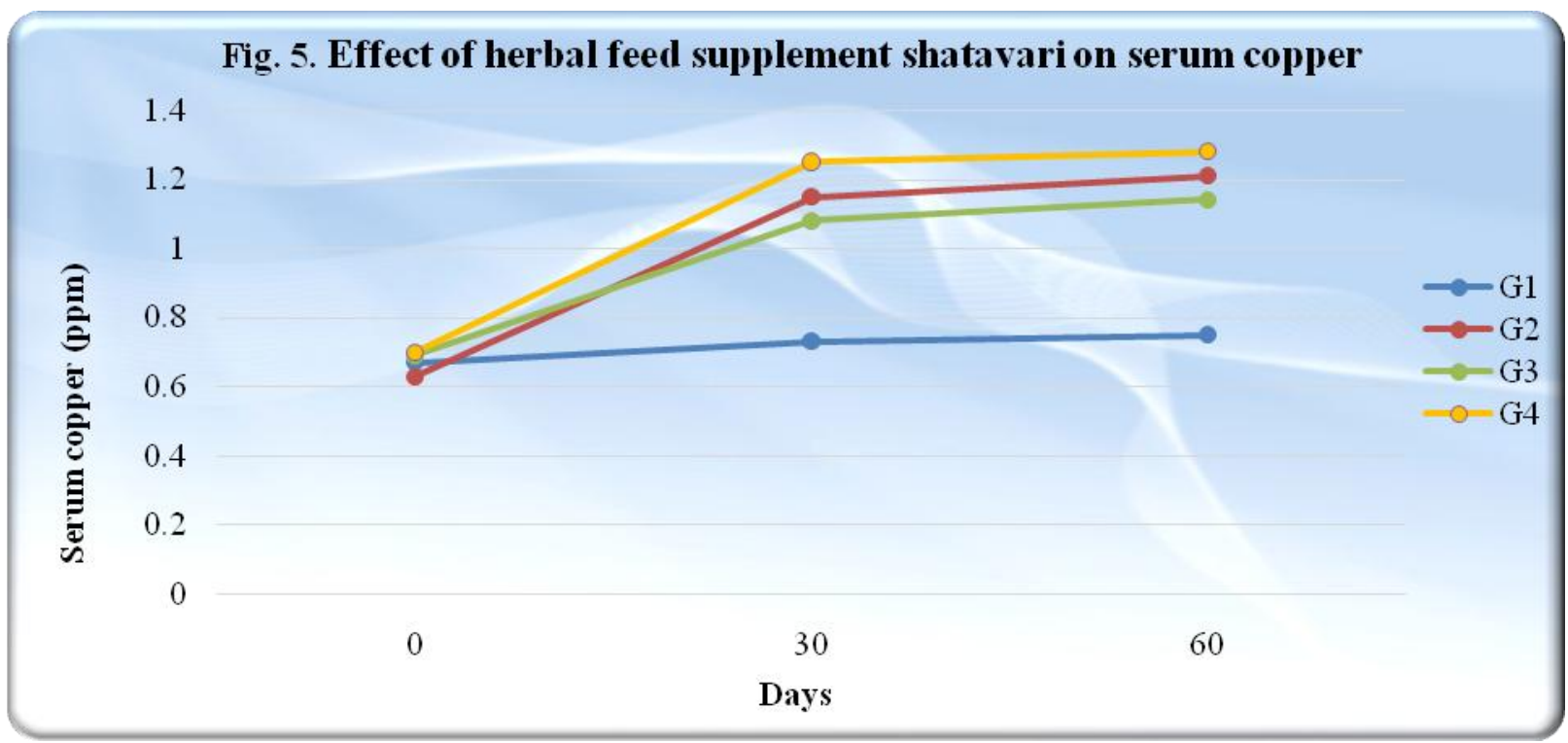

The statistical analysis of data revealed highly significant $\quad(\mathrm{P} \leq 0.01) \quad$ effect due to supplementation of herb shatavari root powder. The maximum serum zinc was found in $G_{3}$ group followed by $G_{4}$ and $G_{2}$ groups and minimum in $G_{2}$ group. Non-significant difference was observed between $\mathrm{G}_{1}$ and $\mathrm{G}_{2}$ groups and also between $\mathrm{G}_{3}$ and $\mathrm{G}_{4}$ groups but $\mathrm{G}_{3}$ and $\mathrm{G}_{4}$ groups differ significantly from $\mathrm{G}_{1}$ and $\mathrm{G}_{2}$ groups.

The results are in agreement with the findings of Sharma (2010), who reported significant effect of polyherbal supplementation in karan fries cows.

\section{Serum copper}

The mean serum copper (ppm) concentrations for the experimental period are presented in Table 6 and illustrated in Figure 5. The statistical analysis of data revealed highly significant $(\mathrm{P} \leq 0.01)$ effect due to supplementation of herb shatavari root powder. The maximum values of serum copper were found in $G_{2}$ and $G_{4}$ groups followed by $G_{3}$ group and minimum in $G_{1}$ group. $G_{2}, G_{3}$ and $G_{4}$ groups do not differ significantly from each other but differ significantly from $\mathrm{G}_{1}$ group.
The results are in agreement with the findings of Sharma (2010), who reported significant effect of polyherbal supplementation in karan fries cows.

In the present study, the effects of herbal feed supplement shatavari (Aspargus racemosus) were assessed in terms of blood mineral profile of crossbred cows. In conclusion, our results showed that the supplementation of shatavari (Aspargus racemosus) root powder to diet affected nutrient metabolism in crossbred cows. In addition, the regulatory mechanisms through which herb feeding effected those blood values in the present study is far from being understood, and further study is required.

\section{References}

Chopra, R.N., Nayar, S.L., and Chopra, I.C., (1956). Effect of some herbal preparations as galactogogue in milch animals. Glossary of Indian Medicinal Plants, CSIR Publication, New Delhi.

Choudhary, B. K. and Kar, A. (1992). Indian Drugs 29: 623.

Ghosal, A.K. and Mathur, G.N. (1988). Studies on trace element status of cattle and sheep in arid zone of Rajasthan. 
Technical annual report II submitted to ICAR by Department of Physiology and Biochemistry College of Veterinary and Animal Science, Bikaner.

Gupta, N., Kumar, A. and Tiwari, D. P. (2005). Effect of herbs as feed additive on nutrient utilization and growth in crossbred heifers fed paddy straw based ration. Indian J. Anim. Sci., 75 (1): 52 55.
ICAR, (2013). Nutrient requirement of livestock and poultry. ICAR, New Delhi.

Sharma, A. (2010). Influence of polyherbal immuno modulator supplementation on production performance and milk quality of Karan-fries cows. Ph.D. Thesis submitted to National Dairy Research Institute (Deemed University), Karnal, Haryana, India.

\section{How to cite this article:}

Vijay Prakash Saini and Sheela Choudhary. 2018. Effect of Feeding Shatavari (Asparagus racemosus) Root Powder on Certain Blood Mineral Profile of Crossbred Cows. Int.J.Curr.Microbiol.App.Sci. 7(09): 1535-1542. doi: https://doi.org/10.20546/ijcmas.2018.709.184 